\title{
Removing Cr(VI) from Aqueous Solutions via Absorption by Green Synthesized PGA-PL-tannin Gel
}

\author{
Haisong Yin ${ }^{1,2}$, Guangming $\mathrm{Li}^{1}$, Xin Qiao ${ }^{3}$, Tingbin $\mathrm{Zhao}^{4}$, Aiyou Sun ${ }^{5}$, \\ Changsheng Qiao ${ }^{1,4,6 *}$
}

${ }^{1}$ Tianjin Engineering Research Center of Microbial Metabolism and Fermentation Process Control, College of Biotechnology, Tianjin University of Science and Technology, Tianjin, China

${ }^{2}$ School of Bioengineering, Tianjin Modern Vocational Technology College, Tianjin, China ${ }^{3}$ School of Biotechnology, Jiangnan University, Wuxi, China ${ }^{4}$ Tianjin Huizhi Biotrans Bioengineering Co., Tianjin, China

${ }^{5}$ State Key Laboratory of Bioreactor Engineering, East China University of Science and Technology, Shanghai, China ${ }^{6}$ Engineering Research Center of Food Biotechnology, Ministry of Education, Tianjin, China

Received: 16 January 2019

Accepted: 28 April 2019

\begin{abstract}
Hexavalent chromium $\mathrm{Cr}(\mathrm{VI})$ has been proven to be harmful to human health and the environment. Polyglutamic acid ( $\gamma$-PGA), polylysine ( $\varepsilon$-PL), and tannin can be designed to make a gel (PGA-PL-tannin) that can efficiently remove $\mathrm{Cr}(\mathrm{VI})$. In this study, the mechanism of $\mathrm{Cr}(\mathrm{VI})$ adsorption by PGA-PL-tannin gel was investigated. The results showed that the rate of $\mathrm{Cr}(\mathrm{VI})$ removal by this gel exceeded $90 \%$ at $\mathrm{pH}$ 6-9. A thermodynamic study of the parameters of $\mathrm{Cr}(\mathrm{VI})$ adsorption by PGA-PL-tannin gel indicated that the process conformed to the Freundlich isothermal adsorption and pseudo second-order adsorption dynamics models, and was a spontaneous and endothermic process. Owing to the interaction between charged functional groups, $\mathrm{Cr}(\mathrm{VI})$ was reduced to trivalent chromium [Cr(III)] after adsorption to the PGA-PL-tannin gel surface. This study demonstrates that PGA-PL-tannin gel could be used as an adsorbent for $\mathrm{Cr}(\mathrm{VI})$ pollution control.
\end{abstract}

Keywords: PGA-PL-tannin, Cr(VI), adsorption, thermodynamics, equilibrium

\section{Introduction}

With rapid industrialization occurring globally, pollution by heavy metal ions has become an urgent environmental problem, causing harm to humans and the environment [1]. Among the heavy metals, hexavalent chromium $[\mathrm{Cr}(\mathrm{VI})]$ is classified as a carcinogen by the International Agency for Research on Cancer due to its strong mutagenicity and teratogenicity $[2,3]$. Chromium is released into waterbodies through wastewater from electroplating, batteries, phosphate fertilizers, mining, pigments, stabilizers, and alloys [4, 5]. Therefore, the removal of chromium-contaminated

*e-mail: qiaochangsheng@ tust.edu.cn 
water is imperative. Many methods for removing heavy metal ions and other types of contaminated water, including ion exchange, precipitation, membrane filtration, electrodialysis, use of a photocatalyst, and adsorption, have been developed [6-8]. The adsorption method is simple, widely applicable, and effective, making it one of the most promising options for sewage purification. Biological macromolecule gels and metal ions in water can form complexes to remove $\mathrm{Cr}$ (IV) effectively [9]. Min et al. synthesized CS-MWNTPAA-PADPA (FG) gel to remove $\mathrm{Cr}(\mathrm{VI})$ from water [10], and at $\mathrm{pH} 2$ the removal rate of $\mathrm{Cr}(\mathrm{VI})$ exceeded $90 \%$. Similarly, Karthik et al. synthesized polyaniline/ silica gel for the removal of $\mathrm{Cr}(\mathrm{VI})$ from water [11]; the adsorption capacity of the gel reached $63.41 \mathrm{mg} / \mathrm{g}$. In addition, Amalraj et al. reported that the combination of threonine and a polypyrrole nanocomposite [12] resulted in a high removal rate of $\mathrm{Cr}(\mathrm{VI})$ at $\mathrm{pH} 2$. However, there were some problems associated with the abovementioned synthetic biological macromolecule gels, such as non-biodegradable material being used in adsorption, complicated preparatory procedures for these gels, and the results being dependent on the $\mathrm{pH}$ of the waterbody.

In this study, we aimed to design a novel biological macromolecule gel (PGA-PL-tannin) that consists of polyglutamic acid ( $\gamma$-PGA), polylysine ( $\varepsilon$-PL), and tannin. To gain insights into the mechanism of $\mathrm{Cr}(\mathrm{VI})$ adsorption by PGA-PL-tannin, Fourier transform infrared (FT-IR) spectroscopy, solid-state ${ }^{13} \mathrm{C}$ nuclear magnetic resonance (NMR) spectroscopy (13C-NMR), inductively coupled plasma (ICP) emission spectrometry, X-ray photoelectron spectroscopy (XPS), and differential scanning calorimetry (DSC) were used to characterize the structure of PGA-PL-tannin. The research results should be helpful for removing $\mathrm{Cr}$ (IV) from the environment.

\section{Materials and Methods}

\section{Materials}

We created a gel containing polyglutamic acid $(\gamma$-PGA), polylysine ( $\varepsilon$-PL), and tannic acid, which did not require a chemical cross-linking agent for synthesis. These materials are biodegradable and benign to the environment. $\gamma$-PGA $\left(\mathrm{M}_{\mathrm{w}}=1000-1200 \mathrm{kDa}\right)$ was obtained from Tianjin Peiyang Biotrans Biotech Co., Ltd. $\varepsilon-P L\left(M_{w}=3500-5000 \mathrm{Da}\right)$ was obtained from Zhejiang Silver-Elephant Bio-engineering Co., Ltd. Tannic acid was obtained from Tianjin Fengchuan Chemical Reagent Technologies Co., Ltd. Potassium dichromate $\left(\mathrm{K}_{2} \mathrm{Cr}_{2} \mathrm{O}_{7}\right)$ used for chromium analysis was of GR grade, and sodium hydroxide $(\mathrm{NaOH})$, hydrochloric acid $(\mathrm{HCl})$, and other reagents used were all of AR grade. Distilled water was used in the experiments described below.

\section{Instrumentation}

An FT-IR spectrophotometer (NEXUS 670; Nicolet, USA), solid-state 13C-CP/MAS NMR (AVANCE AV 400; Bruker, Switzerland), ICP-OES (Optima 5300DV; PerkinElmer, USA), XPS (Kratos Axis Ultra; Kratos, UK), DSC (DSC204F1 Phoenix; Netasch, Germany), and a thermostat oscillator (SKY-2112B; SUKUN, China) were used in this work.

\section{Experimental Methodology}

\section{Preparation of PGA-PL-tannin Gel}

At room temperature, $50 \mathrm{~mL}$ of $60 \mathrm{~g} / \mathrm{L} \gamma$-PGA solution was mixed with $50 \mathrm{~mL}$ of $60 \mathrm{~g} / \mathrm{L}$ tannic acid solution and $30 \mathrm{~mL}$ of $60 \mathrm{~g} / \mathrm{L} \varepsilon-\mathrm{PL}$ solution, followed by stirring slowly for $10 \mathrm{~min}$. The process did not require $\mathrm{pH}$ adjustment.

\section{Adsorption of Cr(VI) by PGA-PL-tannin Gel}

A total of $0.6 \mathrm{~g}$ of the PGA-PL-tannin gel was added to $100 \mathrm{~mL}$ of $3 \mathrm{mg} / \mathrm{L} \mathrm{K}_{2} \mathrm{Cr}_{2} \mathrm{O}_{7}$ in a $500 \mathrm{~mL}$ Erlenmeyer flask. Next, the mixed solution was placed in a rotary shaker and stirred at $20^{\circ} \mathrm{C}$ and $150 \mathrm{r} / \mathrm{min}$, and the solution was adjusted to $\mathrm{pH} 7 \mathrm{using} 0.2 \mathrm{~mol} / \mathrm{L}$ $\mathrm{HCl}$ or $0.2 \mathrm{~mol} / \mathrm{L} \mathrm{NaOH}$. Samples were collected at specific intervals to measure the residual concentration of chromium ions using ICP-OES instruments. Three parallel samples were analyzed.

The percentage removal of $\mathrm{Cr}(\mathrm{VI})$ ions was calculated using the following equation:

$$
R(\%)=\frac{c_{0}-c_{\mathrm{t}}}{c_{0}} \times 100
$$

...where $\mathrm{C}_{0}(\mathrm{mg} / \mathrm{L})$ is the initial concentration of $\mathrm{Cr}(\mathrm{VI})$ ions and $\mathrm{C}_{\mathrm{t}}(\mathrm{mg} / \mathrm{L})$ is the concentration at time $\mathrm{t}$.

Removal capacity $(\mathrm{mg} / \mathrm{g})$ was obtained from the following equation:

$$
q_{\mathrm{e}}=\frac{\left(c_{0}-c_{\mathrm{t}}\right) V}{m}
$$

...where (L) is the volume of the $\mathrm{Cr}(\mathrm{VI})$ ion solution and $m$ is the amount of gel in $\mathrm{g}$.

\section{Influence of $\mathrm{pH}$ on Gel Adsorption of $\mathrm{Cr}(\mathrm{VI})$}

To determine the influence of $\mathrm{pH}$ on the gel adsorption of $\mathrm{Cr}(\mathrm{VI}), 0.2 \mathrm{~mol} / \mathrm{L} \mathrm{HCl}$ or $0.2 \mathrm{~mol} / \mathrm{L}$ $\mathrm{NaOH}$ was added into a $500 \mathrm{~mL}$ conical flask containing $100 \mathrm{~mL}$ of $3 \mathrm{mg} / \mathrm{L} \quad \mathrm{K}_{2} \mathrm{Cr}_{2} \mathrm{O}_{7}$ solution (initial concentration) to adjust the $\mathrm{pH}$ to $2,3,4,5,6,7,8$, 9, and 10. A total of $0.6 \mathrm{~g}$ of gel was added into the $500 \mathrm{~mL}$ conical flask and the solution was shaken at $150 \mathrm{r} / \mathrm{min}$ in a thermostatic oscillator. The concentration of chromium ions remaining in the solution after $3 \mathrm{~h}$ was 
analyzed. Three parallel samples were run for each $\mathrm{pH}$ value.

\section{Influence of Time and Initial Concentration on Gel Adsorption of $\mathrm{Cr}(\mathrm{VI})$}

To determine the influence of time and initial concentration on gel adsorption of $\mathrm{Cr}(\mathrm{VI})$, a total of $100 \mathrm{~mL}$ of $\mathrm{Cr}(\mathrm{VI})$ with initial concentrations of 3, 4, $5,6,7$, and $8 \mathrm{mg} / \mathrm{L}$ was placed into $500 \mathrm{~mL}$ conical flasks. Then, $0.6 \mathrm{~g}$ of gel was added into each flask and the solution was shaken at $150 \mathrm{r} / \mathrm{min}$ in a thermostatic oscillator. Contact times were 2, 3, 4, and $5 \mathrm{~h}$. The liquid adsorption of residual chromium ions was analyzed. Three parallel samples were run for each contact time.

\section{Adsorption Isotherms}

The $\mathrm{Cr}(\mathrm{VI})$ adsorption was tested using two classic isotherms (i.e., Langmuir and Freundlich) under varying experimental conditions. The correlation coefficient $\left(R^{2}\right)$ was derived from the degree of fit between the experimental data and isotherms.

The Langmuir adsorption model is widely used in the study of adsorption. It measures the accumulation of a single monolayer on an energetically uniform surface, across which the adsorbed molecules do not interact [13, 14]. The general Langmuir isotherm relationship can be transformed into a linear form for easy computation of primary parameters [15]:

$$
\frac{1}{q_{\mathrm{e}}}=\frac{1}{q_{\mathrm{m}}}+\frac{1}{K_{\mathrm{L}} c_{e} q_{\mathrm{m}}}
$$

...where $(\mathrm{mg} / \mathrm{g})$ is the binding capacity at equilibrium concentration of $c_{e}, q_{m}(\mathrm{mg} / \mathrm{g})$ is the maximum adsorption capacity, and $K_{L}(\mathrm{~L} / \mathrm{mg})$ is a parameter related to the energy of adsorption.

The Freundlich adsorption model assumes that different adsorption sites exist on an irregular solidphase surface with different adsorption energy to interact with adsorbed species [16]. The general Freundlich isotherm relationship can be transformed into a linear form for easy computation of primary parameters [17]:

$$
\ln q_{\mathrm{e}}=\ln K_{\mathrm{F}}+\frac{1}{n} \ln c_{\mathrm{e}}
$$

...where $K_{\mathrm{F}}$ and $n$ are constants representing adsorption capacity $(\mathrm{mg} / \mathrm{g})$ and intensity, respectively.

\section{Thermodynamics of PGA-PL-tannin Gel Adsorption of $\mathrm{Cr}(\mathrm{VI})$}

The van't Hoff equation is the basic method for calculating adsorption thermodynamic parameters [18-20]. Thermodynamic parameters associated with the adsorption - that is, standard free energy change
$(\Delta G)$, standard enthalpy change $(\Delta H)$, and standard entropy change $(\Delta S)$ - were calculated using equations 5 and 6 :

$$
\Delta G=-R T \ln K_{\mathrm{L}}
$$

...where $R(8.314 \mathrm{~J} / \mathrm{mol} / \mathrm{K})$ is the ideal gas constant, $\mathrm{T}(\mathrm{K})$ is the absolute temperature, $K_{\mathrm{L}}(\mathrm{L} / \mathrm{g})$ is the standard thermodynamic equilibrium constant, and $\Delta G$ is the standard free energy change of sorption $(\mathrm{kJ} / \mathrm{mol})$. The standard thermodynamic equilibrium constant can be expressed in terms of $\Delta H$ and $\Delta S$ as a function of temperature:

$$
\ln K_{\mathrm{L}}=-\frac{\Delta H}{R \times T}+\frac{\Delta S}{R}
$$

...where $\Delta H$ is the standard enthalpy change $(\mathrm{kJ} / \mathrm{mol})$ and $\Delta S$ is the standard entropy change $(\mathrm{kJ} / \mathrm{mol} / \mathrm{K})$. The values of $\Delta H$ and $\Delta S$ can be determined from the slope and intercept of linear regression of $K_{\mathrm{L}}$ vs. 1/T.

\section{Kinetics of PGA-PL-tannin Gel Adsorption of $\mathrm{Cr}(\mathrm{VI})$}

The dynamic curve of the rate of gel adsorption of Cr(VI) was obtained by pseudo first-order and pseudo second-order dynamic adsorption models [1, 21]. The pseudo first-order kinetic equation describes the total rate of adsorption using a kinetics equation, as shown in Eq. 7:

$$
\ln \left(q_{\mathrm{e}}-q_{\mathrm{t}}\right)=\ln q_{\mathrm{e}}-k_{1} t
$$

...where $q_{\mathrm{e}}$ and $q_{\mathrm{t}}(\mathrm{mg} / \mathrm{g})$ are the quantity of adsorption by quality at equilibrium or time $(t)$, and $k_{1}\left(\mathrm{~h}^{-1}\right)$ is the pseudo first-order rate constant.

$$
\frac{t}{q_{\mathrm{t}}}=\frac{1}{q_{\mathrm{e}}} t+\frac{1}{k_{2} \cdot q_{\mathrm{e}}^{2}}
$$

The pseudo second-order adsorption kinetics rate equation (pseudo second-order rate equation) has been proposed by Ho [22, 23], as shown in Eq. 8. It also describes the adsorption of heavy metal ions and also belongs to the total rate equation describing adsorption kinetics [24].

\section{Results and Discussion}

\section{Characterization of PGA-PL-tannin Gel Structure}

PGA-PL-tannin gel is a polymer comprising $\gamma$-PGA, $\varepsilon$-PL, and tannin. It is efficient for $\mathrm{Cr}(\mathrm{VI})$ adsorption, and has good selectivity and stability. To identify the surface functional groups of PGA-PL-tannin gel, the FT-IR spectra of tannic acid, $\varepsilon$-PL, $\gamma$-PGA, 


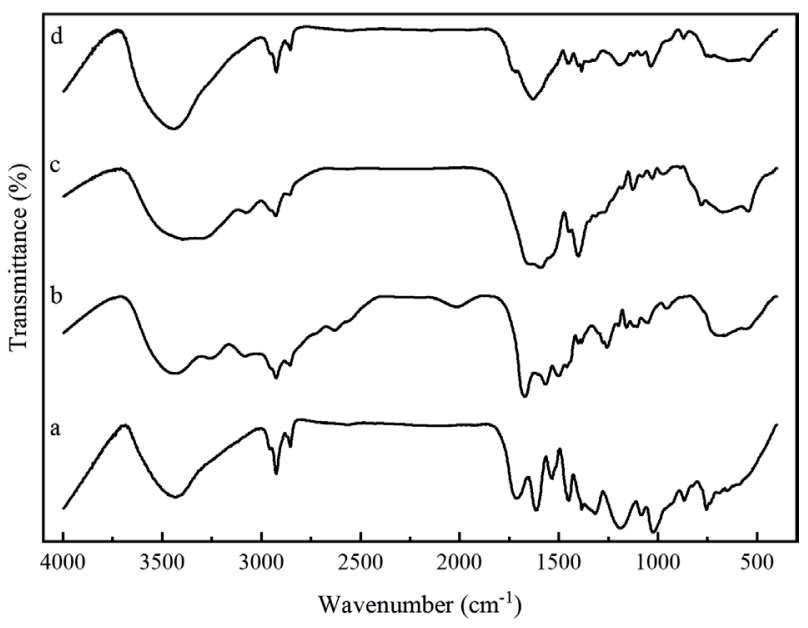

Fig. 1. FT-IR spectra: a) tannic acid; b) $\varepsilon-P L$; c) $\gamma$-PGA; d) PGAPL-tannin gel.

and PGA-PL-tannin gel were measured. As shown in Fig. 1, a predominant peak at $3410 \mathrm{~cm}^{-1}$ associated with $\mathrm{OH}$ stretching vibration was identified, along with a peak at $1710 \mathrm{~cm}^{-1}$ assigned to $\mathrm{C}=\mathrm{O}$ and $-\mathrm{NHCO}$ - stretch at around $1565 \mathrm{~cm}^{-1}$. The other peaks of the PGA-PLtannin gel did not differ with respect to those of $\gamma$-PGA,

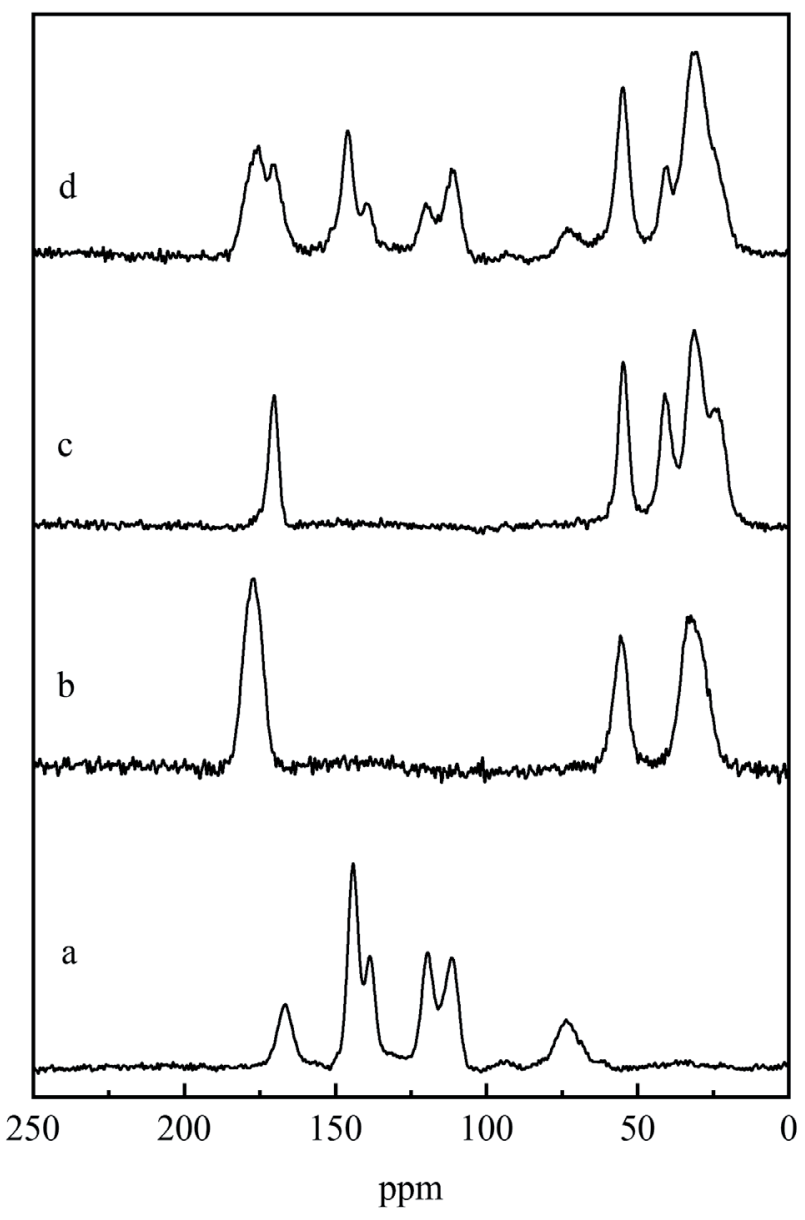

Fig. 2. Solid-state ${ }^{13} \mathrm{C}-\mathrm{NMR}$ spectrum of the gel: a) tannic acid; b) $\varepsilon$-PL; c) $\gamma$-PGA; d) PGA-PL-tannin gel.
$\varepsilon$-PL, and tannin acid, which indicated that $\gamma$-PGA, $\varepsilon$-PL, and tannin acid were probably fixed through a mode of non-chemical interaction, such as electrostatic attraction or hydrogen bonding.

Fig. 2 shows the solid-state 13C-NMR spectrum of the gel. The chemical shifts at 24.746 and $32.311 \mathrm{ppm}$ are assigned to $-\mathrm{CH}_{2}-$ groups. The chemical shifts at 169.449 and $175.196 \mathrm{ppm}$ are assigned to $-\mathrm{COOH}$ and $\mathrm{C}=\mathrm{O}$, respectively. The chemical shifts at 41.262 and $55.578 \mathrm{ppm}$ are assigned to $-\mathrm{CH}_{2}-\mathrm{NH}-$ and $-\mathrm{C}-\mathrm{NH}_{2}$, respectively. Therefore, the structures $\gamma$-PGA and $\varepsilon-\mathrm{PL}$ can be considered to be present in the gel. Chemical shifts between 110.261 and $145.140 \mathrm{ppm}$ are consistent with the production of tannins. Combined with the FT-IR spectra, the results show that the gel consisted of $\gamma$-PGA, $\varepsilon$-PL, and tannic acid, created through polymerization that occurs via hydrogen bonds and generates new biological macromolecules.

\section{Effect of Solution $\mathrm{pH}$ on Gel Adsorption of $\mathrm{Cr}(\mathrm{VI})$}

Solution $\mathrm{pH}$ plays an important role in the process of metal ion sorption. Generally, the surface charge of the sorbents and the existing form of the heavy metal ions were affected by the solution $\mathrm{pH}$ [25]. PGA-PLtannin gel has strong adsorption capacity, achieving removal of $\mathrm{Cr}(\mathrm{VI})$ at a rate of more than $90 \%$. However, the gel adsorption of $\mathrm{Cr}(\mathrm{VI})$ was affected by the $\mathrm{pH}$ of the solution. To determine the effect of $\mathrm{pH}$ on $\mathrm{Cr}(\mathrm{VI})$ sorption by the PGA-PL-tannin gel, $\mathrm{pH}$ of the solution was adjusted to between $\mathrm{pH} 2$ and 10 . The results showed that the removal rate of $\mathrm{Cr}(\mathrm{VI})$ was increased between $\mathrm{pH} 2$ and $\mathrm{pH}$ 6, and reached a maximum at $\mathrm{pH} \mathrm{6}$, and then sharply dropped to below $40 \%$ at $\mathrm{pH}$ values greater than 9 (Fig. 3). Free amino and carboxyl molecules were protonated at lower $\mathrm{pH}$; thus, the electrostatic adsorption of positively charged molecules with the solution of $\mathrm{CrO}_{4}^{2-}$ achieved the best removal rate. When the $\mathrm{pH}$ was

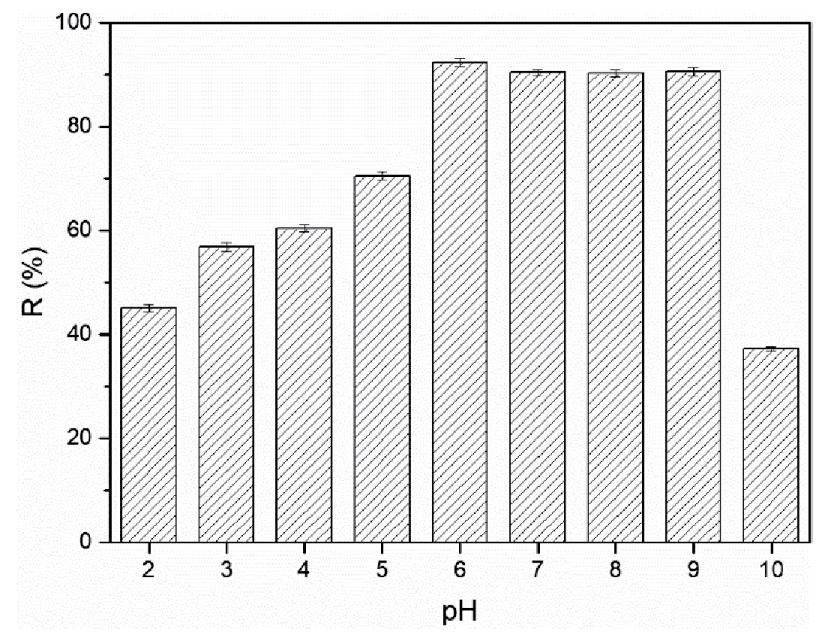

Fig. 3. Effect of initial $\mathrm{pH}$ on $\mathrm{Cr}(\mathrm{VI})$ adsorption by PGA-PLtannin gel. 




Fig. 4. Effect of reaction time and initial concentration on $\mathrm{Cr}(\mathrm{VI})$ adsorption by PGA-PL-tannin gel.

greater than 9, the removal rate of $\mathrm{Cr}(\mathrm{VI})$ was found to be low, which could be attributed to the competition between $\mathrm{CrO}_{4}^{2-}$ ions and $\mathrm{OH}^{1-}$ ions for the sorption sites of the sorbent surface [26].

\section{Effects of Reaction Time and Initial Concentration on Gel Adsorption of $\mathrm{Cr}(\mathrm{VI})$}

The gel adsorption of $\mathrm{Cr}(\mathrm{VI})$ was affected by both reaction time and initial concentration (Fig. 4). The results showed that the removal rate of $\mathrm{Cr}(\mathrm{VI})$ followed a downward trend with the increase of $\mathrm{Cr}(\mathrm{VI})$ concentration; when the initial concentration reached $3 \mathrm{mg} / \mathrm{L}$, the removal rate of $\mathrm{Cr}(\mathrm{VI})$ was the highest $(78.53 \%)$. When the reaction time was $3 \mathrm{~h}$, which was favorable for the removal of $\mathrm{Cr}(\mathrm{VI})$ - especially for a higher initial concentration of $\mathrm{Cr}(\mathrm{VI})$, the removal rate of $\mathrm{Cr}(\mathrm{VI})$ was the highest. It was speculated that this may be related to the negative surface charge and number of gel adsorption sites (i.e., by amino groups on the gel/amino protons generated). For instance, a large number of active adsorption sites would allow high electrostatic attraction for $\mathrm{Cr}(\mathrm{VI})$ adsorption. Over time, there would be less residual adsorption until the point of saturation [26]. After gel adsorption saturation of $\mathrm{Cr}(\mathrm{VI})$, electrostatic repulsion dissociation would occur. Thus, the number of active sites of the gel would become the factor limiting the adsorption process [25].

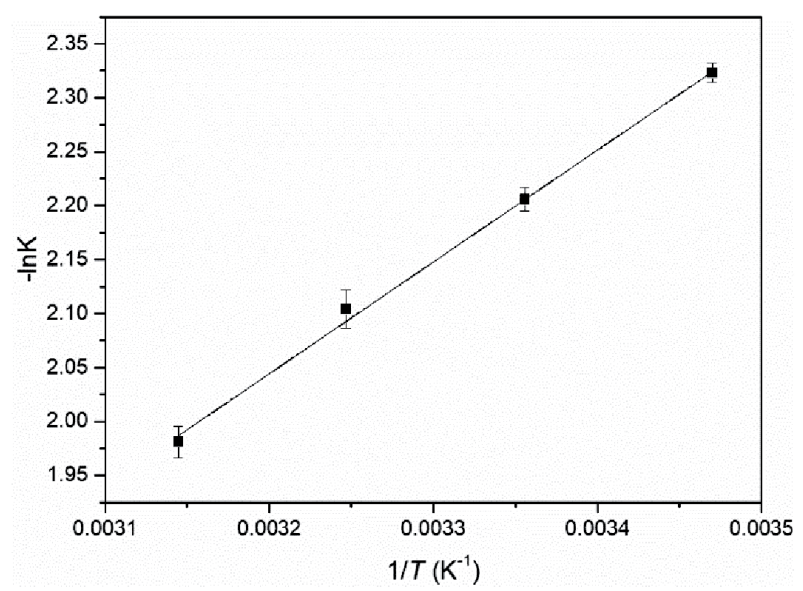

Fig. 5. Plots of $-\operatorname{lnK}$ vs. $1 / \mathrm{T}$ for the adsorption of $\mathrm{Cr}(\mathrm{VI})$ by PGA-PL-tannin gel.

\section{Isotherms of PGA-PL-tannin Gel Adsorption of $\mathrm{Cr}(\mathrm{VI})$}

The relationship between the adsorbent and the adsorption capacities was elucidated via adsorption isotherms, where both the Langmuir and Freundlich adsorption models were used to describe the $\mathrm{Cr}(\mathrm{VI})$ adsorption on PGA-PL-tannin gel. Considering the Langmuir and Freundlich models for gel adsorption of $\mathrm{Cr}(\mathrm{VI})$, the $R^{2}$ values were greater than 0.89 and the curve fit better (Table 1) when adopting the Freundlich model; the results thus indicated that it was more suitable to describe gel adsorption of $\mathrm{Cr}(\mathrm{VI})$ than the Langmuir isotherm. Experimental results showed that the adsorption phenomena may be inhomogeneous on the surface in the multilayer adsorption process. Under the Freundlich model, the fit of the results could be further increased at temperatures between $288 \mathrm{~K}$ and $318 \mathrm{~K}$; however, the value of $\mathrm{n}$ changed slightly with the increase of temperature.

\section{Thermodynamics of PGA-PL-tannin Gel Adsorption of Cr(VI)}

Gel adsorption of $\mathrm{Cr}(\mathrm{VI})$ was determined using the van't Hoff equation of linear regression analysis (Fig. 5), which was a plot of - vs. 1/T. The correlation was strong $\left(\mathrm{R}^{2}=0.9993\right)$, which indicated that the calculation method was suitable for the process of gel adsorption

Table 1. Parameters of Langmuir and Freundlich models for $\mathrm{Cr}(\mathrm{VI})$ adsorption onto gel.

\begin{tabular}{|c|c|c|c|c|c|c|}
\hline \multirow{2}{*}{ Temperature } & \multicolumn{3}{|c|}{ Langmuir model } & \multicolumn{3}{c|}{ Freundlich model } \\
\cline { 2 - 7 } & $K_{\mathrm{L}}(\mathrm{L} / \mathrm{mg})$ & $q_{\mathrm{m}}(\mathrm{mg} / \mathrm{g})$ & $R^{2}$ & $K_{\mathrm{F}}$ & $\mathrm{n}$ & $R^{2}$ \\
\hline $288 \mathrm{~K}$ & 0.0233 & 0.5186 & 0.9027 & 0.2675 & 1.025 & 0.9018 \\
\hline $298 \mathrm{~K}$ & 0.5685 & 0.6768 & 0.9219 & 0.3243 & 2.332 & 0.8993 \\
\hline $308 \mathrm{~K}$ & 0.6525 & 0.5875 & 0.7079 & 0.2312 & 2.186 & 0.9803 \\
\hline $318 \mathrm{~K}$ & 0.7804 & 0.6533 & 0.7730 & 0.2806 & 2.285 & 0.9901 \\
\hline
\end{tabular}



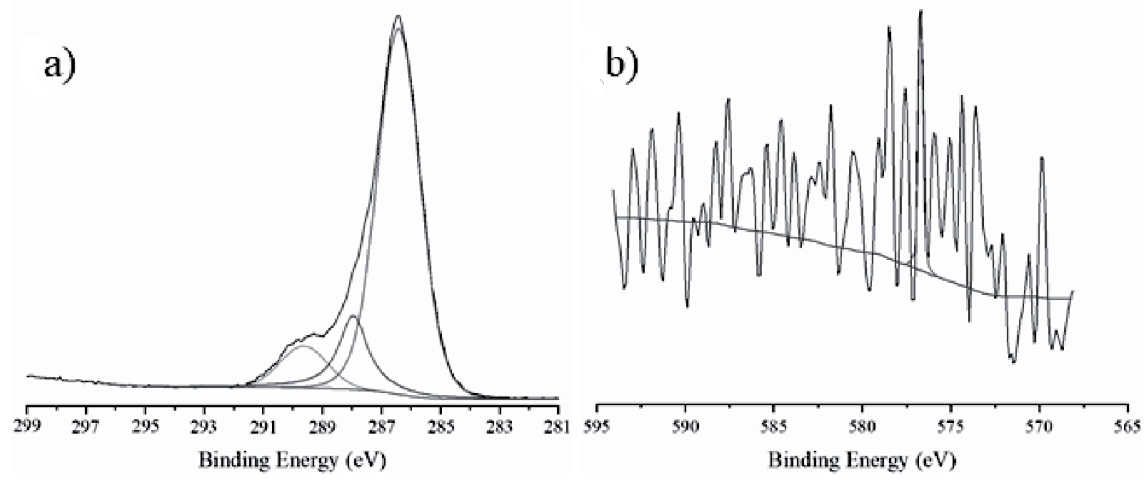

Fig. 6. XPS spectra of $\mathrm{Cr}(\mathrm{VI})$ adsorbed gel: a) gel C1s; b) gel after adsorption of $\mathrm{Cr}(\mathrm{VI})$.

of $\mathrm{Cr}(\mathrm{VI})$. In the process of $\mathrm{Cr}(\mathrm{VI})$ adsorption, the free energy change showed a downward trend with the increase of experimental temperature $(288 \mathrm{k}, \Delta G=5.537 \mathrm{KJ} / \mathrm{mol} ; 318 \mathrm{k}, \Delta G=5.236 \mathrm{KJ} /$ $\mathrm{mol})$. Experimental results showed that the spontaneous gel adsorption of $\mathrm{Cr}(\mathrm{VI})$ may be improved at higher temperatures. Furthermore, its endothermic nature was confirmed by the change of enthalpy $(\Delta H=8.58 \mathrm{KJ} / \mathrm{mol})$ in the process of gel adsorption of $\mathrm{Cr}(\mathrm{VI})$, and the adsorption of $\mathrm{Cr}(\mathrm{VI})$ could be improved by increasing the temperature. For the $\mathrm{Cr}(\mathrm{VI})$ adsorption process $(\Delta S=0.01045 \mathrm{KJ} / \mathrm{mol} / \mathrm{K})$, that gel adsorption of $\mathrm{Cr}(\mathrm{VI})$ was a process of entropy increase; namely, the disorder of the adsorption system increased after the adsorption of $\mathrm{Cr}(\mathrm{VI})$ [21].

\section{Kinetics of PGA-PL-tannin Gel Adsorption of $\mathrm{Cr}(\mathrm{VI})$}

The pseudo first-order and pseudo second-order adsorption kinetics models were used for fitting analysis. The results showed that the pseudo secondorder dynamics equation successfully described the gel adsorption kinetics of the $\mathrm{Cr}(\mathrm{VI})$ model $\left(R^{2}=0.9979\right)$. The pseudo second-order adsorption rate constant $k_{2}$ increased with an increase in initial concentration, especially from a low concentration of $\mathrm{Cr}(\mathrm{VI})$. Thus, as the initial concentration increased from 3 to $6 \mathrm{mg} / \mathrm{L}, k_{2}$ increased from -5.128 to $8.264 \mathrm{~g} / \mathrm{mg} / \mathrm{h}$, and then decreased as the initial concentration of $\mathrm{Cr}(\mathrm{VI})$ continued to increase. At a low initial concentration, the influence of the solution concentration on the adsorption rate increased.

\section{Mechanism of PGA-PL-tannin Gel Adsorption of $\mathrm{Cr}(\mathrm{VI})$}

To explore the mechanisms of PGA-PL-tannin gel adsorption of $\mathrm{Cr}(\mathrm{VI})$, three peaks were detected in XPS spectra and C1s spectra (Fig. 6a): the carbon in the C-N at $286.572 \mathrm{eV}$; the carbon in the amide bond $\mathrm{O}=\mathrm{C}-\mathrm{NH}$ at $287.973 \mathrm{eV}$; and the carbon in the acid ester $\mathrm{O}-\mathrm{C}=\mathrm{O}$ at $290.026 \mathrm{eV}$. Thus, the carbon in the gel is mainly from the $\mathrm{C}-\mathrm{N}$ key carbon. From images showing that the binding energy is $\mathrm{Cr}_{2 \mathrm{p} 3 / 2}$, after adsorption, $\mathrm{Cr}(\mathrm{VI})$ in the gel appeared to be reduced to $\mathrm{Cr}$ (III) (Fig. 6b). In the process of adsorption, $\mathrm{Cr}(\mathrm{VI})$ and the first amino/amino combination allow the $\mathrm{Cr}(\mathrm{VI})$ to be reduced to $\mathrm{Cr}$ (III). With the gel on the surface, the- $\mathrm{NH}_{2}$ hydrogen atoms, and the electronegativity of larger nitrogen atoms, shared electrons favor nitrogen atoms, making positively charged hydrogen atoms into almost naked protons. When negatively charged chromic acid is exposed to nearby radical anions, the protonation of amino acids on the gel and chromic acid radical anions in oxygen atoms produces electrostatic attraction (i.e., hydrogen bonding), which achieves the adsorption [27].

\section{Conclusions}

This paper introduces a method of $\mathrm{Cr}(\mathrm{VI})$ adsorption using PGA-PL-tannin gel. The adsorption of $\mathrm{Cr}(\mathrm{VI})$ onto PGA-PL-tannin gel were affected by contact time, initial concentration of gel, and $\mathrm{pH}$. And the value of maximum removal rate of $\mathrm{Cr}(\mathrm{VI})$ was obtained when the initial concentration reached

Table 2. Calculated kinetic parameters for the adsorption of $\mathrm{Cr}(\mathrm{VI})$ onto gel.

\begin{tabular}{|c|c|c|c|c|c|c|}
\hline \multirow{2}{*}{$\begin{array}{c}\text { Concentration } \\
(\mathrm{mg} / \mathrm{L})\end{array}$} & \multicolumn{3}{|c|}{ Pseudo-first-order } & \multicolumn{3}{c|}{ Pseudo-second-order } \\
\cline { 2 - 7 } & $k_{1}\left(\mathrm{~h}^{-1}\right)$ & $q_{\mathrm{e}}(\mathrm{mg} / \mathrm{g})$ & $R^{2}$ & $k_{2}(\mathrm{~g} / \mathrm{mg} / \mathrm{h})$ & $q_{\mathrm{e}}(\mathrm{mg} / \mathrm{g})$ & $R^{2}$ \\
\hline 3 & 0.2221 & 0.2187 & 0.8027 & -5.128 & 0.2812 & 0.9979 \\
\hline 6 & 0.1260 & 0.2037 & 0.8604 & 8.264 & 0.3181 & 0.9954 \\
\hline 9 & 0.1336 & 0.3244 & 0.8723 & 3.571 & 0.3049 & 0.9909 \\
\hline
\end{tabular}


$3 \mathrm{mg} / \mathrm{L}$ and the reaction time was $3 \mathrm{~h}$. PGA-PL-tannin gel adsorption of $\mathrm{Cr}(\mathrm{VI})$ aligns with the Freundlich isotherm adsorption model. Furthermore, the kinetics of PGA-PL-tannin gel adsorption of $\mathrm{Cr}(\mathrm{VI})$ aligns with the pseudo second-order equation $k_{2}=0.7927 \mathrm{mg} / \mathrm{g} / \mathrm{h}$. In the process of adsorption, $\mathrm{Cr}(\mathrm{VI})$ and the first amino/ amino combination allow the $\mathrm{Cr}(\mathrm{VI})$ to be reduced to Cr(III) by PGA-PL-tannin gel. Desorption of chromium ions into chromium salts after recycling renders the adsorption gel biodegradable as harmless amino acids, such as glutamic acid and lysine. Adsorption thermodynamics, adsorption kinetics, and gel structure characterization results were combined to analyze the adsorption mechanism. Overall, PGA-PL-tannin gel proved to be a highly efficient adsorption material to remove $\mathrm{Cr}(\mathrm{VI})$ ions from water. Furthermore, PGAPL-tannin gel is advantageous because its synthesis is simple, it is reusable and biodegradable, the metal ions can be recycled after desorption, and secondary pollution is not released into the environment.

\section{Acknowledgments}

This work was supported by the Foundation of Tianjin Municipal Science and Technology Commission (Nos. 17PTGCCX00190, 17PTSYJC00080, 17YFCZZC00310, and 16YFXTSF00460), the Foundation of Tianjin Engineering Research Center of Microbial Metabolism and Fermentation Process Control, PR China (No. ZXKF20180301), and the Foundation of Engineering Research Center of Food Biotechnology, Ministry of Education, PR China (No. SPZX10-18).

\section{Conflict of Interest}

The authors declare no conflict of interest.

\section{References}

1. JAVADIAN H. Adsorption performance of suitable nanostructured novel composite adsorbent of poly(Nmethylaniline) for removal of heavy metal from aqueous solutions. Journal of Industrial and Engineering Chemistry, 20 (6), 4344, 2014.

2. DONG X., MA L.Q., LI Y. Characteristics and mechanisms of hexavalent chromium removal by biochar from sugar beet tailing. Journal of Hazardous Materials, 190 (1-3), 909, 2011.

3. CLEMENTINO M., SHI X., ZHANG Z. Oxidative stress and metabolic reprogramming in $\mathrm{Cr}(\mathrm{VI})$ carcinogenesis. Current Opinion in Toxicology, 8, 20, 2018.

4. MADALA S., NADAVALA S. K., VUDAGANDLA S., BODDU V. M., ABBURI K. Equilibrium, kinetics and thermodynamics of Cadmium (II) biosorption on to composite chitosan biosorbent. Arabian Journal of Chemistry, 10, S1883, 2017.

5. KAHU S.S., SHEKHAWAT A., SARAVANAN D., JUGADE R.M. Two fold modified chitosan for enhanced adsorption of hexavalent chromium from simulated wastewater and industrial effluents. Carbohydrate Polymers, 146, 264, 2016.

6. ZHANG L., XIA W., LIU X., ZHANG W. Synthesis of titanium cross-linked chitosan composite for efficient adsorption and detoxification of hexavalent chromium from water. Journal of Materials Chemistry A, 3 (1), 331, 2015.

7. SOUNTHARARAJAH D.P., LOGANATHAN P., KANDASAMY J., VIGNESWARAN S. Adsorptive removal of heavy metals from water using sodium titanate nanofibres loaded onto GAC in fixed-bed columns. Journal of Hazardous Materials, 287, 306, 2015.

8. BARRERA-DÍAZ C.E., LUGO-LUGO V., BILYEU B. A review of chemical, electrochemical and biological methods for aqueous $\mathrm{Cr}(\mathrm{VI})$ reduction. Journal of Hazardous Materials, 223-224, 1, 2012.

9. JIANG L., LIU S., LIU Y., ZENG G., GUO Y., YIN Y., CAI X., ZHOU L., TAN X., HUANG X. Enhanced adsorption of hexavalent chromium by a biochar derived from ramie biomass ( Boehmeria nivea (L.) Gaud.) modified with $\beta$-cyclodextrin/poly(L-glutamic acid). Environmental Science \& Pollution Research International, 24 (30), 1, 2017.

10. KIM M.K., SHANMUGA SUNDARAM K., ANANTHA IYENGAR G., LEE K.-P. A novel chitosan functional gel included with multiwall carbon nanotube and substituted polyaniline as adsorbent for efficient removal of chromium ion. Chemical Engineering Journal, 267, 51, 2015.

11. KARTHIK R., MEENAKSHI S. Removal of hexavalent chromium ions using polyaniline/silica gel composite. Journal of Water Process Engineering, 1, 37, 2014.

12. AMALRAJ A., SELVI M.K., RAJESWARI A., CHRISTY E.J.S., PIUS A. Efficient removal of toxic hexavalent chromium from aqueous solution using threonine doped polypyrrole nanocomposite. Journal of Water Process Engineering, 13, 88, 2016.

13. MARWANI H.M., ALBISHRI H.M., JALAL T.A., SOLIMAN E.M. Study of isotherm and kinetic models of lanthanum adsorption on activated carbon loaded with recently synthesized Schiff's base. Arabian Journal of Chemistry, 10, S1032, 2017.

14. HU Q., XIAO Z., XIONG X., ZHOU G., GUAN X. Predicting heavy metals' adsorption edges and adsorption isotherms on $\mathrm{MnO}_{2}$ with the parameters determined from Langmuir kinetics. Journal of Environmental Sciences, 27, 207, 2015.

15. POGUBEROVIĆ S.S., KRČMAR D.M., MALETIĆ S.P., KÓNYA Z., PILIPOVIĆ D.D.T., KERKEZ D.V., RONČEVIĆ S.D. Removal of As(III) and $\mathrm{Cr}(\mathrm{VI})$ from aqueous solutions using "green" zero-valent iron nanoparticles produced by oak, mulberry and cherry leaf extracts. Ecological Engineering, 90, 42, 2016.

16. SHAKER M.A. Thermodynamics and kinetics of bivalent cadmium biosorption onto nanoparticles of chitosan-based biopolymers. Journal of the Taiwan Institute of Chemical Engineers, 47, 79, 2015.

17. SHAHWAN T., ABU SIRRIAH S., NAIRAT M., BOYACI E., EROĜLU A.E., SCOTT T.B., HALLAM K.R. Green synthesis of iron nanoparticles and their application as a Fenton-like catalyst for the degradation of aqueous cationic and anionic dyes. Chemical Engineering Journal, 172 (1), 258, 2011.

18. MASSON S., VAULOT C., REINERT L., GUITTONNEAU S., GADIOU R., DUCLAUX L. Thermodynamic study of seven micropollutants adsorption 
onto an activated carbon cloth: Van't Hoff method, calorimetry, and COSMO-RS simulations. Environmental Science and Pollution Research, 24 (11), 10005, 2017.

19. KANTONEN S.A., HENRIKSEN N.M., GILSON M.K. Accounting for apparent deviations between calorimetric and van't Hoff enthalpies. Biochimica et Biophysica Acta (BBA) - General Subjects, 1862 (3), 692, 2018.

20. NGUYEN M.L., JUANG R.-S. Improved biosorption of phenol using crosslinked chitosan beads after modification with histidine and Saccharomyces cerevisiae. Biotechnology and Bioprocess Engineering, 20 (3), 614, 2015.

21. GUPTA N., KUSHWAHA A.K., CHATTOPADHYAYA M.C. Adsorptive removal of $\mathrm{Pb}^{2+}, \mathrm{Co}^{2+}$ and $\mathrm{Ni}^{2+}$ by hydroxyapatite/chitosan composite from aqueous solution. Journal of the Taiwan Institute of Chemical Engineers, $\mathbf{4 3}$ (1), 125, 2012.

22. GUPTA N., KUSHWAHA A.K., CHATTOPADHYAYA M.C. Adsorption studies of cationic dyes onto Ashoka (Saraca asoca) leaf powder. Journal of the Taiwan Institute of Chemical Engineers, 43 (4), 604, 2012.
23. XU S., WANG Z., GAO Y., ZHANG S., WU K. Adsorption of Rare Earths(III) Using an Efficient Sodium Alginate Hydrogel Cross-Linked with Poly- $\gamma$-Glutamate. PLOS ONE, 10 (5), e0124826, 2015.

24. XU C., WANG H., YANG W., MA L., LIN A. Expanded Graphite Modified by $\mathrm{CTAB}-\mathrm{KBr} / \mathrm{H}_{3} \mathrm{PO}_{4}$ for Highly Efficient Adsorption of Dyes. Journal of Polymers \& the Environment, 26 (3), 1206, 2018.

25. JIN X., LIU Y., TAN J., OWENS G., CHEN Z. Removal of $\mathrm{Cr}(\mathrm{VI})$ from aqueous solutions via reduction and absorption by green synthesized iron nanoparticles. Journal of Cleaner Production, 176, 929, 2018.

26. GHEJU M., BALCU I., MOSOARCA G. Removal of $\mathrm{Cr}(\mathrm{VI})$ from aqueous solutions by adsorption on $\mathrm{MnO}_{2}$. Journal of Hazardous Materials, 310, 270, 2016.

27. LIM S.F., ZHENG Y.M., ZOU S.W., CHEN J.P. Characterization of copper adsorption onto an alginate encapsulated magnetic sorbent by a combined FT-IR, XPS, and mathematical modeling study. Environmental Science and Technology, 42 (7), 2551, 2008. 